\title{
Effect of Application of Soil Amendments on the PAHs Level in the Fire-Affected Forest Soil
}

\author{
Petra Martínez Barroso', Jan Winkler², Jan Oulehla', Magdalena Daria Vaverková',3* \\ 1 Department of Applied and Landscape Ecology, Faculty of AgriSciences, Mendel University in Brno, \\ Zemědělská 1, 61300 Brno, Czech Republic \\ 2 Department of Plant Biology, Faculty of AgriSciences, Mendel University in Brno, Zemědělská 1, 61300 Brno, \\ Czech Republic \\ 3 Institute of Civil Engineering, Warsaw University of Life Sciences - SGGW, ul. Nowoursynowska 159, 02-776 \\ Warsaw, Poland \\ * Corresponding author's e-mail: magda.vaverkova@uake.cz
}

\begin{abstract}
Polycyclic aromatic hydrocarbons (PAHs) are introduced to the environment from anthropogenic and natural sources. The most significant natural source of PAH are wildfires and volcanic eruptions. The PAHs occurring in the soil mostly bind to the root system of plants. Phytodegradation, specifically rhizospheric degradation, can reduce the PAH levels in soil with the help of plants roots. A pot experiment was conducted to study the effect of application of soil amendments on the PAHs level in the burnt soil (BS). The aim of this study was to assess the effect of application of soil amendments (compost, biochar, and bentonite) on the PAHs level after performing experiment with two grass species (Lolium perenne, Festuca rubra). Biochar and compost turned out to be the most effective amendments, regardless of the used grass species. Phytomanaged BS without added amendments also demonstrated the potential for PAH dissipation, but only in the case of Festuca rubra. It has been proven that the application of soil amendments together with the test grass species induced important changes in the BS properties (alteration of soil $\mathrm{pH}$ with related change of $\mathrm{K}_{\text {ow }}$ of individual PAHs; root system on which soil microorganisms thrive) which evoked an increased bioavailability of PAHs.
\end{abstract}

Keywords: burnt soil, PAH, soil amendment, biochar, compost, bentonite, rhizoremediation.

\section{INTRODUCTION}

Polycyclic aromatic hydrocarbons (PAHs) are hydrophobic organic compounds formed by two or more fused benzene rings generated during imperfect combustion of organic materials in low oxygen concentrations, namely during pyrogenic, petrogenic and biological processes (Abdel-Shafy et al., 2016). They are introduced to the environment from anthropogenic and natural sources and occur in all components of the environment - in the air, water, and soil (Ren et al., 2021). Thus, the natural sources of PAHs receive less public attention than the PAHs coming from the anthropogenic sources. The most significant natural source of PAH are wildfires and volcanic eruptions (Menzie et al., 1992; Raudonytė-Svirbutavičienė et al., 2022). Wildfire has recently become a major issue and has been increasingly associated with climate change (Aponte et al., 2016; FernandezAnez et al. 2021). Several studies indicate that the frequency of fires has been also caused by other factors, such as fire suppression policies, afforestation, and abandonment of rural areas (Doerr et al., 2016; Agoston et al. 2018). Abandoned areas become naturally revitalized, and the accumulated biomass promotes the spread of potential fires. The fire can also affect neighbouring areas that have not been hit by the fire. Soil is one of the components of the environment that come into direct contact with fire (Terzano et al. 2021; Zhou et al., 2022). 
PAHs are persistent environmental contaminants with varying degrees of biological activity, especially toxicity, carcinogenicity, and mutagenicity (Menzie et al., 1992; Zhou et al. 2022). Their recalcitrance to natural degradation processes is given by their chemical stability and physicochemical properties which are dependent on their molar mass. The higher the molar mass, the higher the resistance to redox reactions and the greater mobility in the environment they have (CCME, 2012) which is dangerous due to their ability to accumulate in organisms.

The chemical composition of the PAHs generated via different processes (pyrogenic, petrogenic and biological) varies. The PAHs of pyrogenic origin are mainly composed of parent PAHs which means they do not contain alkyl groups, heteroatoms, or hydroxides, while the PAHs from petrogenic origin do contain alkylated forms (Wang et al., 2008). Due to the way PAHs are formed, they occur in the environment almost exclusively in complex mixtures (Zelinkova et al., 2015). It was found that the metabolism of PAH mixtures differs from the metabolism of individual PAHs because of enzyme competition and other effects (Desai et al., 2008). Their potential as a human carcinogen was identified by Environmental Protection Agency (EPA) based on accumulated experience and advances in the knowledge on cancer assessment (CCME, 2010). EPA determined a set of 16 PAHs which are frequently found in environmental samples (Lamichchane et al., 2016). Thus, it became standard for environmental analysis to express the PAHs content as a sum of concentrations of these 16 PAHs (Girardin, 2020).

The behaviour of PAHs in soils is influenced by their physico-chemical properties. Soils are formed by 3 phases - gaseous, liquid, and solid. The gaseous and liquid phases maintain the contaminants in bioavailable form while the solid phase causes their retention because they bind on it (Alexander, 1995). When sorbed on the finest soil particles, PAHs can be transported to groundwater (Abdel-Shafy et al., 2016). Because of their lipophilicity, they are attracted by the fat component in the root membrane (Kukavica et al., 2007) and bind to it. Usually, PAHs are not transported to other parts of the plant from the root system where they adhere to the epidermis surface or outdoor root tissue. Only low molar mass PAHs, i.e. 2- and 3- benzene rings PAH (e.g. Naphthalene, Acenaphthene, Anthracene,
Fluorene, Phenanthrene), can be transported to other parts of the plant (Alagić et al., 2015). The PAHs in soils are transformed mainly by microbial degradation. Many soil aerobic bacteria can catalyse the oxidation of substances by molecular oxygen. In the air, PAHs usually sorb on the surface of solid particles. When sorbed on the surface of airborne dust, they can be transmitted to very distant places. Although the PAHs with high molar mass are relatively stable, they are reactive to gases such as hydrogen, oxygen, ozone, $\mathrm{NO}_{2}$, $\mathrm{NO}_{3}$ and $\mathrm{OH}$ radicals. Temperature, light, ozone, and oxygen can further increase their reactivity (Nayebzadeh et al., 2017).

Phytodegradation, specifically rhizospheric degradation, is one of sensitive ways to reduce the PAH levels in soil with the help of plants and their roots (Lamichchane et al., 2016; Nayebzadeh et al., 2017). The roots have developed a mechanism for using toxic substances from the environment as a carbon source for their growth. They secrete exudates which create a favourable environment for bacteria and fungi and thus stimulate a microbial degradation of organic pollutants including PAHs (Lamichchane et al., 2016; Nayebzadeh et al., 2017). Certain plants release the substances that can make the contaminants more soluble and hence more available for degradation (Desai et al., 1997). The rhizospheric degradation was studied, for example, on industrially contaminated surfaces (Eskandary et al., 2017) or on the substrates spiked with selected individual PAHs under laboratory conditions (Chang et al., 2003; Wei et al., 2010). The possibility of using a combination of bacteria and plants aimed at reducing the amount of selected PAHs was also investigated (Eskandary et al., 2017; Abdullah et al., 2020). The areas contaminated by natural source of PAH (e.g. PAH levels after wildfires) are usually investigated only as far as the levels and distribution of PAHs are concerned (Tsibart et al., 2014; Faboya et al. 2020). Another approach to tackle the issue of PAH-contaminated soils is the bioaugmentation and biostimulation. Bioaugmentation consists in inoculating the contaminated environment by indigenous or allochtonous microorganisms (Huang et Ye, 2020; Ferraro et al., 2021) which are capable of degrading PAHs. In a research by Ferraro et al. (2021), the effectiveness of the bioaugmentation was proven on the soil contaminated by selected PAHs. Biostimulation is a technique during which a contaminated environment is modified 
by the introduction of limiting nutrients in order to enhance microbial growth and thus the remediation process (Straube et al., 2003).

Phytodegradation of the areas contaminated by natural PAH sources that would be supported by soil amendment is an insufficiently researched area and this study has focused on this topic. Due to the relative chemical stability of PAHs in soil, the interaction between them and the application of soil amendments is expected to be indirect. Soil amendments can induce better soil conditions from which plants can benefit and develop stronger root system that might promote quicker repopulation of soil by rhizospheric microbes and thus the degradation of PAHs can be enhanced.

The aim of this study was to contribute to clarification of the relationship between PAH contamination and the effect of application of soil amendments (biochar, compost, and bentonite) under the conditions of burnt forest soil. The research was based on performing a pot experiment with two grass species (Lolium perenne, Festuca rubra).

\section{MATERIAL AND METHODS}

\section{Site description and collection of samples}

The study area is situated in Southern Bohemia nearby the Vlčetínec village, $(49.2650800 \mathrm{~N}$, 15.0540075E), Czech Republic (CR) and belongs to the Pelhrrimov bioregion whose current landscape of which is characterized by fen-meadows, smaller ponds, fragments of submontane beech wood, and prevailing culture spruce groves (Culek, 2013). The forest in which the study took place is a culture spruce grove with following tree species composition: $80 \%$ Norway spruce (Picea abies), 10\% Scots pine (Pinus sylvestris), $2.6 \%$ European larch (Larix decidua), 0.7\% Silver fir (Abies alba), and minority representation of deciduous species e.g., European beech (Fagus sylvatica), Black alder (Alnus glutinosa), Silver birch (Betula pendula). The scientific names of plant species were taken from the database of the Czech flora and vegetation (Pladias, 2018).

The soil is a typical acidic cambisol, formerly called brown forest soil, and $\mathrm{pH}_{\mathrm{KCl}} 3.4$ was measured in the subjected locality. The low $\mathrm{pH}$ can be assigned to strong fall of coniferous litter (needles) (Goldblum et al., 2009) and to atmospheric acidic deposition (Yang et al., 2015). The locality had suffered from a bark beetle calamity and the most hit part had to be cut down (an area of approximately $100 \times 100 \mathrm{~m}$ ). The large trunks were cleared from branches and removed from the area. The left branches and brushwood were locally burnt on several places (Figure 1). The burning took place on $23^{\text {rd }}$ May 2020 and the fire was maintained for several days. These fires can be considered as a moderate to high intensity fires, because the surface of the soil remained covered

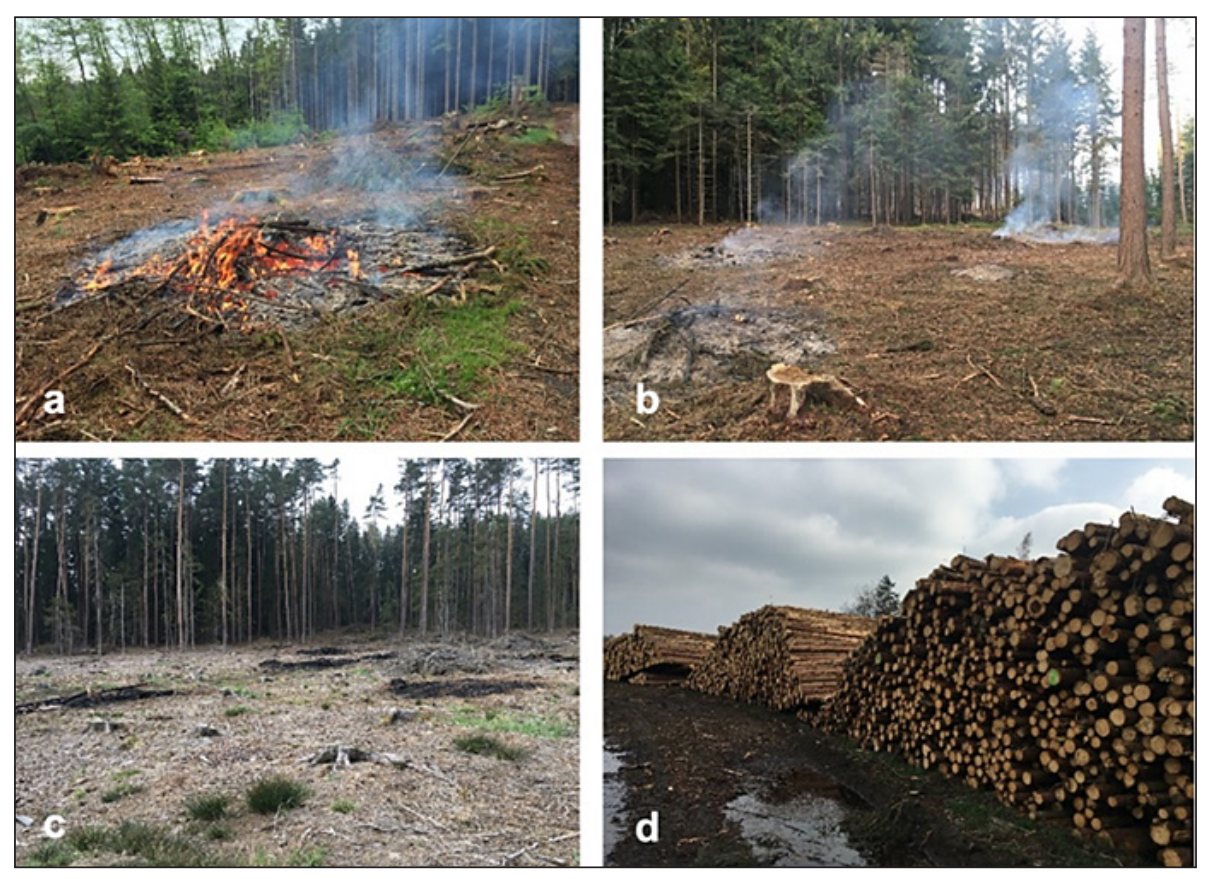

Figure 1. a) piling fire; b) burnt away fires; c) burnt points; d) felled logs infested by bark beetle calamity 
Table 1. Locations of sampling of burnt points

\begin{tabular}{|c|c|c|c|}
\hline Burnt points & Latitude & Longitude & Altitude [m] \\
\hline 1 & $49^{\circ} 16^{\prime} 13.0 ” \mathrm{~N}$ & $15^{\circ} 02^{\prime} 10.3^{\prime \prime} \mathrm{E}$ & 588.4 \\
\hline 2 & $49^{\circ} 16^{\prime} 12.9^{\prime \prime} \mathrm{N}$ & $15^{\circ} 02^{\prime} 10.3^{\prime \prime} \mathrm{E}$ & 589.6 \\
\hline 3 & $49^{\circ} 16^{\prime} 13.1^{\prime \prime} \mathrm{N}$ & $15^{\circ} 02^{\prime} 10.9^{\prime \prime} \mathrm{E}$ & 588.3 \\
\hline 4 & $49^{\circ} 16^{\prime} 13.2 " \mathrm{~N}$ & $15^{\circ} 02^{\prime} 11.6^{\prime \prime} \mathrm{E}$ & 588.2 \\
\hline 5 & $49^{\circ} 16^{\prime} 13.3^{\prime \prime} \mathrm{N}$ & $15^{\circ} 02^{\prime} 11.8^{\prime \prime} \mathrm{E}$ & 587.5 \\
\hline 6 & $49^{\circ} 16^{\prime} 13.4^{\prime \prime} \mathrm{N}$ & $15^{\circ} 02^{\prime} 11.9^{\prime \prime} \mathrm{E}$ & 586.7 \\
\hline 7 & $49^{\circ} 16^{\prime} 13.8^{\prime \prime} \mathrm{N}$ & $15^{\circ} 02^{\prime} 12.4^{\prime \prime} \mathrm{E}$ & 584.2 \\
\hline 8 & $49^{\circ} 16^{\prime} 14.2^{\prime \prime} \mathrm{N}$ & $15^{\circ} 02^{\prime} 12.2^{\prime \prime} \mathrm{E}$ & 584.9 \\
\hline 9 & $49^{\circ} 16^{\prime} 14.5^{\prime \prime} \mathrm{N}$ & $15^{\circ} 02^{\prime} 11.8^{\prime \prime} \mathrm{E}$ & 584.7 \\
\hline 10 & $49^{\circ} 16^{\prime} 14.7^{\prime \prime} \mathrm{N}$ & $15^{\circ} 02^{\prime} 11.5^{\prime \prime} \mathrm{E}$ & 584.8 \\
\hline 11 & $49^{\circ} 16^{\prime} 15.1^{\prime \prime} \mathrm{N}$ & $15^{\circ} 02^{\prime} 11.5^{\prime \prime} \mathrm{E}$ & 586.0 \\
\hline 12 & $49^{\circ} 16^{\prime} 14.7^{\prime \prime} \mathrm{N}$ & $15^{\circ} 02^{\prime} 10.7^{\prime \prime} \mathrm{E}$ & 583.9 \\
\hline 13 & $49^{\circ} 16^{\prime} 14.7^{\prime \prime} \mathrm{N}$ & $15^{\circ} 02^{\prime} 10.0^{\prime \prime} \mathrm{E}$ & 583.4 \\
\hline 14 & $49^{\circ} 16^{\prime} 14.6^{\prime \prime} \mathrm{N}$ & $15^{\circ} 02^{\prime} 09.9^{\prime \prime} \mathrm{E}$ & 581.7 \\
\hline 15 & $49^{\circ} 16^{\prime} 13.8^{\prime \prime} \mathrm{N}$ & $15^{\circ} 02^{\prime} 09.1^{\prime \prime} \mathrm{E}$ & 583.4 \\
\hline 16 & $49^{\circ} 16^{\prime} 13.9^{\prime \prime} \mathrm{N}$ & $15^{\circ} 02^{\prime} 08.9^{\prime \prime} \mathrm{E}$ & 582.5 \\
\hline 17 & $49^{\circ} 16^{\prime} 13.8^{\prime \prime} \mathrm{N}$ & $15^{\circ} 02^{\prime} 08.2^{\prime \prime} \mathrm{E}$ & 581.5 \\
\hline 18 & $49^{\circ} 16^{\prime} 13.8^{\prime \prime} \mathrm{N}$ & $15^{\circ} 02^{\prime} 07.9^{\prime \prime} \mathrm{E}$ & 581.6 \\
\hline 19 & $49^{\circ} 16^{\prime} 14.0 ” \mathrm{~N}$ & $15^{\circ} 02^{\prime} 07.7^{\prime \prime} \mathrm{E}$ & 581.7 \\
\hline
\end{tabular}

by whitish and black ash. The ash is a diagnostic parameter of burn severity and a sign of complete combustion of the fuel (Dudaite et al., 2011; Bodí et al., 2014); it confirms that high temperatures were reached during these fires. Temperatures between $200-500^{\circ} \mathrm{C}$ leave the black ash and temperatures exceeding $510^{\circ} \mathrm{C}$ form whitish ash.

The postfire soil samples were collected one week after the burning was finished from all the 19 points in which the fires were set. Each burnt point measured approximately $3 \times 3 \mathrm{~m}^{2}$ and was localized by a GPS Garmin etrex 10 device (Table 1 ).

The samples of BS including the layer of ash were collected from the burnt points from topsoil $(0-0.2 \mathrm{~m})$ with a use of a metal spade; $4 \mathrm{~kg}$ of BS comprising of 10 individual subsamples were obtained from each burnt point. Altogether, 76 $\mathrm{kg}$ of BS were collected and transported in plastic vessels to a laboratory in Mendel University in Brno, Department of Landscape and Applied Ecology where the soil was spread in a layer of $30 \mathrm{~mm}$ height and left to air-dry at $25^{\circ} \mathrm{C}$ for 2 weeks. After the air-drying, coarse materials (e.g. stones, uncombusted twigs) were manually removed; then, the soil was homogenized and sieved through a 5-mm mesh. The soil was classified as loamy sand ( $72 \%$ sand, $25 \%$ silt, $3 \%$ clay) based on the performed sieve analysis and with the use of the Soil Texture Triangle. Non-burnt
Table 2. Locations of sampling of unburnt points

\begin{tabular}{|c|c|c|c|}
\hline Burnt points & Latitude & Longitude & Altitude [m] \\
\hline $20 \mathrm{~N}$ & $49^{\circ} 16^{\prime} 14.3^{\prime \prime} \mathrm{N}$ & $15^{\circ} 02^{\prime} 09.4^{\prime \prime} \mathrm{E}$ & 578.0 \\
\hline $21 \mathrm{~N}$ & $49^{\circ} 16^{\prime} 15.1^{\prime \prime} \mathrm{N}$ & $15^{\circ} 02^{\prime} 10.4^{\prime \prime} \mathrm{E}$ & 583.2 \\
\hline $22 \mathrm{~N}$ & $49^{\circ} 16^{\prime} 14.3^{\prime \prime} \mathrm{N}$ & $15^{\circ} 02^{\prime} 11.9^{\prime \prime} \mathrm{E}$ & 580.6 \\
\hline $23 \mathrm{~N}$ & $49^{\circ} 16^{\prime} 13.8^{\prime \prime} \mathrm{N}$ & $15^{\circ} 02^{\prime} 11.0^{\prime \prime} \mathrm{E}$ & 577.6 \\
\hline $24 \mathrm{~N}$ & $49^{\circ} 16^{\prime} 13.5^{\prime \prime} \mathrm{N}$ & $15^{\circ} 02^{\prime} 09.5^{\prime \prime} \mathrm{E}$ & 578.7 \\
\hline $25 \mathrm{~N}$ & $49^{\circ} 16^{\prime} 13.1{ }^{\prime \prime} \mathrm{N}$ & $1^{\circ} 02^{\prime} 08.3^{\prime \prime} \mathrm{E}$ & 577.4 \\
\hline
\end{tabular}

forest soil in the amount of $4 \mathrm{~kg}$ were removed from 6 different spots (Table 2) within the study area and subjected to the same treatment for comparison purposes. The non-burnt forest soil has been exposed to the smoke from the piling fires for the whole period of their lasting.

\section{Experimental design}

A pot experiment was carried out to study the effect of application of soil amendments on the PAHs level in the BS. The samples of unburnt soil and BS (reference samples) were subjected to the same treatment, only without planting the tested grass species. The PAH values were measured in all the experimental variants of soil samples including the reference samples after finishing the pot experiment. The timing of PAH analysis after performing the pot experiment was decided, since time is an important factor affecting the values of PAHs and needs to be considered (discussed in section Results and Discussion). The analysis of roots was rejected due to the fact that they are not a suitable matrix for the analysis of PAH levels after a fire. They are degraded during the sample preparation, as they have to be rinsed with water so that the adhered soil is removed. This process can mechanically remove PAHs from the root surface and thus can skew the results. The values measured in reference samples were compared with the PAH values measured in the experimental variants. The treatments are indicated in Table 3. Furthermore, the effectiveness of two plant species (Lolium perenne, Festuca rubra) was evaluated. The PAH values were measured in the accredited laboratory.

\section{Pot experiment}

A mixture of enriched BS was prepared by mixing 3\% w/w of each soil amendment $(270 \mathrm{~g})$ with BS (8 $730 \mathrm{~g})$ and placed to flowerpots (height $140 \mathrm{~mm}$, width $140 \mathrm{~mm}$, length $760 \mathrm{~mm}$ ) with 
Table 3. Arrangement of pot experiment

\begin{tabular}{|c|l|c|}
\hline $\begin{array}{c}\text { Variant } \\
\text { label }\end{array}$ & \multicolumn{1}{|c|}{ Treatment } & $\begin{array}{c}\text { Experimental } \\
\text { variant with plant }\end{array}$ \\
\hline V_001 & BS $+3 \%$ w/w bentonite & Lolium perenne \\
\hline V_002 & BS $+3 \%$ w/w compost & Lolium perenne \\
\hline V_003 & BS $+3 \%$ w/w biochar & Lolium perenne \\
\hline V_004 & $100 \%$ BS & Lolium perenne \\
\hline V_005 & BS $+3 \%$ w/w bentonite & Festuca rubra \\
\hline V_006 & BS $+3 \%$ w/w compost & Festuca rubra \\
\hline V_007 & BS $+3 \%$ w/w biochar & Festuca rubra \\
\hline V_008 & $100 \%$ BS & Festuca rubra \\
\hline V_009 & $100 \%$ Unburnt soil & Control \\
\hline V_010 & $100 \%$ BS & Control \\
\hline
\end{tabular}

bottom perforation. The dose of 3\% w/w has been selected based on the previous studies carried out by Radziemska et al. (2017) and Martinez Barroso et al. (2020). A detailed characterization of soil amendments is shown in Table 4a and Table 4b. In total, 10 flowerpots were prepared: 6 flowerpots with enriched BS (3 for testing with Lolium perenne and 3 for testing with Festuca rubra), 3 flowerpots with $100 \%$ BS and 1 flowerpot with unburnt soil.

All the flowerpots were watered till reaching the water holding capacity and kept in darkness at $22^{\circ} \mathrm{C}$ for one week to allow the amendments to react with the BS. The same procedure was carried out with the flowerpots with $100 \% \mathrm{BS}$ and unburnt soil. During the week, the soil was watered once more. After the properties of the mixture were balanced, the soil from each experimental variant was divided to 5 pots (each with diameter $152 \mathrm{~mm}$, height $140 \mathrm{~mm}$ and $140 \mathrm{~mm}$ depth) and $1 \mathrm{~g}$ of seeds of Lolium perenne and Festuca rubra, respectively, were sown to each pot and watered every third day. The pot experiment was devised for 2 months (23 ${ }^{\text {rd }}$ June $2020-25^{\text {th }}$ August 2020) and was carried out in the air-conditioned laboratory where the temperature was maintained at $18^{\circ} \mathrm{C}$. The pots were organized randomly within the laboratory and natural daylight was used as a light source. The order of the flowerpots was changed every 2 weeks. After 1 month, the aboveground biomass was cut to allow the root system to become stronger. The flowerpots with $100 \%$ BS and unburnt soil which were not subjected to phytomanagement, were treated equally to the phytomanaged experimental variants.

The cut above-ground biomass was dried and stored for future analysis. After the second month, the pot experiment was terminated; the above-ground and under-ground biomass was carefully removed, separated and dried. The soil was dried as well. Each sample was labelled indicating the treatment (combination of soil amendment and plant species and date).

\section{Chemical analysis of soil}

The samples of soil after carrying out the pot experiment were sent to the accredited laboratory for analysis of physical and organic parameters. Description of the used methods is an integral part of the Certificate of Accreditation (ALS Global, 2021).

\section{Physical parametres}

$\mathrm{pH}_{\mathrm{KCl}}$ - determined electrochemically in suspension with $\mathrm{H}_{2} \mathrm{O}, \mathrm{CaCl}_{2}, \mathrm{BaCl}_{2}$ based on $\mathrm{C}_{\mathrm{SN}}$

Table 4a. Detailed characterization of biochar and compost

\begin{tabular}{|l|c|c|}
\hline \multirow{2}{*}{\multicolumn{2}{|c|}{ Properties }} & \multicolumn{2}{c|}{ Soil amendment } \\
\cline { 2 - 3 } & Biochar $^{1}$ & Compost $^{2}$ \\
\hline Dry matter (d.m.) at $105^{\circ} \mathrm{C}[\%]$ & 90.3 & 92.4 \\
\hline Total Nitrogen & 3050 & 13300 \\
\hline Active $\mathrm{pH}[-]$ & 9.3 & 7.9 \\
\hline $\mathrm{Cd}^{*}$ & $<0.40$ & $<0.40$ \\
\hline $\mathrm{Cr}^{*}$ & 2.32 & 31.0 \\
\hline $\mathrm{Cu}^{*}$ & 14.2 & 53.7 \\
\hline $\mathrm{Ni}^{*}$ & 5.8 & 17.9 \\
\hline $\mathrm{Pb}^{*}$ & 1.7 & 16.4 \\
\hline $\mathrm{Zn}^{*}$ & 135 & 204 \\
\hline $\mathrm{Ca}^{*}$ & 30500 & - \\
\hline $\mathrm{C}: \mathrm{N}$ ratio & - & 11.9 \\
\hline
\end{tabular}

* mg.kg-1 d.m.; soil amendments analyzed in an accredited laboratory;

${ }^{1}$ Biochar - a registered soil conditioner bought from (Prauhel, 2020);

${ }^{2}$ Compost - a registered organic fertilizer produced in a local municipal composting plant (Centralni kompostarna, 2020).

Table 4b. Detailed characterization of bentonite

\begin{tabular}{|c|c|}
\hline \multirow{2}{*}{ Properties } & Soil amendment \\
\cline { 2 - 2 } & Bentonite \\
\hline $\mathrm{SiO}_{2}{ }^{*}$ & 73.2 \\
\hline $\mathrm{Al}_{2} \mathrm{O}_{3}{ }^{*}$ & 11.4 \\
\hline $\mathrm{CaO}^{*}$ & 2.67 \\
\hline $\mathrm{Na}_{2} \mathrm{O}^{*}$ & 0.31 \\
\hline $\mathrm{MgO}^{*}$ & 1.05 \\
\hline $\mathrm{K}_{2} \mathrm{O}^{*}$ & 2.58 \\
\hline $\mathrm{Fe}_{2} \mathrm{O}_{3}{ }^{*}$ & 0.29 \\
\hline
\end{tabular}

$* \% \mathrm{w} / \mathrm{w}$; All data from $(\mathrm{Mi}, 2017)$ 
ISO 10390, ČSN EN 12176:1999, ČSN EN 13037, ČSN EN 15933, ČSN 46 5735, ÖNORM L10861, US EPA Method 9045D; US EPA 9040C.

Dry matter at $105^{\circ} \mathrm{C}$ - determined gravimetrically, humidity calculated from measured values based on ČSN ISO 11465, ČSN EN 12880, ČSN EN 14346 and ČSN ISO 11465, ČSN EN 12880, ČSN EN 14346:2007, ČSN 465735

\section{Organic parametres}

PAH - determination of semivolatile organic substances by gas chromatography with mass spectrometry (MS) or MS/MS detection and calculation of sum of semivolatile organic substances from the measured values based on US EPA 8270D, US EPA 8082A, ČSN EN 15527, ISO 18287, ISO 10382, ČSN EN 15308. 16 Priority pollutant PAHs characterized in Table 5 were analyzed.

\section{Statistical analysis}

The sum of PAHs was statistically evaluated by ANOVA and by Fischer LSD test. The measured values of individual PAHs were processed by multidimensional analysis designated for processing ecological data, Principal Component Analysis (PCA) and subsequently by Redundancy Analysis (RDA). PCA enables to capture the impact of factors of the environment (test setting) on the monitored quantities (PAHs). Owing to the visualization of the results by RDA analysis, it is also possible to determine the relationships between the individual monitored quantities (PAHs) under the impact of different factors of the environment. The length of the data gradient calculated by PCA was 2.92; therefore, the RDA analysis was used for further data treatment. Logarithmic data transformation was performed before RDA analysis. Proof testing was performed using the Monte-Carlo test and 999 permutations were calculated. The calculations were performed using the computer program Canoco 5.0 (Ter Braak et al., 2012).

\section{RESULTS AND DISCUSSION}

Detailed results of the chemical analysis of PAHs in individual experimental variants as well as in unphytomanged burnt and unburnt soil are presented in Table 6. Mean PAH values and Fischer LSD test results are shown in Table 7.

Acenaphtene, Acenaphtylene, and Anthracene were under the LOD in all experimental variants after performing the pot experiment. These low molar mass PAHs have a relatively short halflife in orders of tens of days in soils (Chanda et al., 2005) and can be degraded by soil microbial organisms (Roslund et al., 2018). The 2-month

Table 5. Selected properties of 16 priority pollutant PAHs

\begin{tabular}{|l|c|c|c|c|c|}
\hline \multicolumn{1}{|c|}{ PAH } & Chemical formula & Benzene rings & Relative molar mass [g.mol ${ }^{-1}$ ] & Log K$_{\text {ow }}$ & WoE $^{1}$ \\
\hline Naphthalene & $\mathrm{C}_{10} \mathrm{H}_{8}$ & 2 & 128.174 & 3.29 & $\mathrm{C}$ \\
\hline Acenaphthylene & $\mathrm{C}_{12} \mathrm{H}_{8}$ & 2 & 152.196 & 4.07 & $\mathrm{D}$ \\
\hline Acenaphthene & $\mathrm{C}_{12} \mathrm{H}_{10}$ & 2 & 154.212 & 3.98 & $\mathrm{D}$ \\
\hline Fluorene & $\mathrm{C}_{13} \mathrm{H}_{10}$ & 2 & 166.223 & 4.18 & $\mathrm{D}$ \\
\hline Anthracene & $\mathrm{C}_{14} \mathrm{H}_{10}$ & 3 & 178.234 & 4.45 & $\mathrm{~B} 2$ \\
\hline Phenantrene & $\mathrm{C}_{14} \mathrm{H}_{10}$ & 3 & 178.234 & 4.45 & $\mathrm{D}$ \\
\hline Fluoranthene & $\mathrm{C}_{16} \mathrm{H}_{10}$ & 3 & 202.256 & 4.90 & $\mathrm{D}$ \\
\hline Pyrene & $\mathrm{C}_{16} \mathrm{H}_{10}$ & 4 & 202.256 & 4.88 & $\mathrm{D}$ \\
\hline Chrysene & $\mathrm{C}_{18} \mathrm{H}_{12}$ & 4 & 228.294 & 5.90 & $\mathrm{~B} 2$ \\
\hline Benzo[a]anthracene & $\mathrm{C}_{18} \mathrm{H}_{12}$ & 4 & 228.294 & 5.61 & $\mathrm{~B} 2$ \\
\hline Benzo[a]pyrene & $\mathrm{C}_{20} \mathrm{H}_{12}$ & 5 & 252.316 & 6.06 & Carcinogenic \\
to humans \\
\hline Benzo[k]fluoranthene & $\mathrm{C}_{20} \mathrm{H}_{12}$ & 4 & 252.316 & 6.06 & B2 \\
\hline Indeno[1,2,3-cd]pyrene & $\mathrm{C}_{12} \mathrm{H}_{12}$ & 5 & 276.331 & 6.58 & B2 \\
\hline Benzo[b]fluoranthene & $\mathrm{C}_{20} \mathrm{H}_{12}$ & 4 & 276.331 & 6.06 & B2 \\
\hline Benzo[g,h,i]perylene & $\mathrm{C}_{22} \mathrm{H}_{12}$ & 6 & 276.331 & 6.50 & $\mathrm{D}$ \\
\hline Dibenzo[a,h]anthracene & $\mathrm{C}_{22} \mathrm{H}_{14}$ & 5 & 278.347 & 6.84 & B2 \\
\hline
\end{tabular}

$\mathrm{K}_{\text {ow }}$ - octanol-water partitioning coefficient; WoE - toxicity as per Weight of Evidence (EPA): B2 - Probable human carcinogen - based on sufficient evidence of carcinogenicity in animals; C - Possible human carcinogen; D - Not classifiable as to human carcinogenicity; All data from (Patel, 2020) unless otherwise indicated; ${ }^{1}$ data from (EPA, 2021) 
Table 6. Distribution of PAHs in individual experimental variants

\begin{tabular}{|c|c|c|c|c|c|c|c|c|c|c|c|}
\hline \multicolumn{2}{|c|}{ Specification } & \multirow{2}{*}{$\begin{array}{c}\text { V_001 } \\
0.077 \pm \\
0.001\end{array}$} & \multirow{2}{*}{$\begin{array}{c}\text { V_002 } \\
0.088 \pm \\
0.001\end{array}$} & \multirow{2}{*}{$\begin{array}{c}\text { V_003 } \\
0.071 \pm \\
0.001\end{array}$} & \multirow{2}{*}{$\begin{array}{c}\text { V_004 } \\
0.081 \pm \\
0.001\end{array}$} & \multirow{2}{*}{$\begin{array}{c}\text { V_005 } \\
0.072 \pm \\
0.001\end{array}$} & \multirow{2}{*}{$\begin{array}{c}\text { V_006 } \\
0.071 \pm \\
0.001\end{array}$} & \multirow{2}{*}{$\begin{array}{c}\text { V_007 } \\
0.121 \pm \\
0.001\end{array}$} & \multirow{2}{*}{$\begin{array}{c}\text { V_008 } \\
0.062 \pm \\
0.001\end{array}$} & \multirow{2}{*}{$\frac{\text { V_009 }}{<0.010}$} & \multirow{2}{*}{$\begin{array}{c}\text { V_010 } \\
2.060 \pm \\
0.008\end{array}$} \\
\hline Naphthalene & $\mathrm{N}$ & & & & & & & & & & \\
\hline Acenaphthylene & Acy & $<0.010$ & $<0.010$ & $<0.010$ & $<0.010$ & $<0.010$ & $<0.010$ & $<0.010$ & $<0.010$ & $<0.010$ & $<0.010$ \\
\hline Acenaphthene & Ace & $<0.010$ & $<0.010$ & $<0.010$ & $<0.010$ & $<0.010$ & $<0.010$ & $<0.010$ & $<0.010$ & $<0.010$ & $<0.010$ \\
\hline Fluorene & $\mathrm{F}$ & $<0.010$ & $<0.010$ & $<0.010$ & $\begin{array}{c}0.011 \pm \\
0.001\end{array}$ & $\begin{array}{c}0.012 \pm \\
0.001\end{array}$ & $<0.010$ & $\begin{array}{c}0.010 \pm \\
0.001\end{array}$ & $<0.010$ & $<0.010$ & $<0.010$ \\
\hline Anthracene & Ant & $<0.010$ & $<0.010$ & $<0.010$ & $<0.010$ & $<0.010$ & $<0.010$ & $<0.010$ & $<0.010$ & $<0.010$ & $<0.010$ \\
\hline Phenantrene & Phe & $\begin{array}{c}0.047 \pm \\
0.001\end{array}$ & $\begin{array}{c}0.033 \pm \\
0.001\end{array}$ & $\begin{array}{c}0.065 \pm \\
0.001\end{array}$ & $\begin{array}{c}0.075 \pm \\
0.001 \\
\end{array}$ & $\begin{array}{c}0.083 \pm \\
0.001\end{array}$ & $\begin{array}{c}0.056 \pm \\
0.001 \\
\end{array}$ & $\begin{array}{c}0.063 \pm \\
0.001\end{array}$ & $\begin{array}{c}0.057 \pm \\
0.001 \\
\end{array}$ & $\begin{array}{c}0.071 \pm \\
0.001 \\
\end{array}$ & $\begin{array}{c}0.146 \pm \\
0.001 \\
\end{array}$ \\
\hline Fluoranthene & $\mathrm{FI}$ & $\begin{array}{c}0.047 \pm \\
0.001\end{array}$ & $\begin{array}{c}0.042 \pm \\
0.001\end{array}$ & $\begin{array}{c}0.116 \pm \\
0.001 \\
\end{array}$ & $\begin{array}{c}0.132 \pm \\
0.001 \\
\end{array}$ & $\begin{array}{c}0.146 \pm \\
0.001\end{array}$ & $\begin{array}{c}0.084 \pm \\
0.001 \\
\end{array}$ & $\begin{array}{c}0.095 \pm \\
0.001\end{array}$ & $\begin{array}{c}0.043 \pm \\
0.001\end{array}$ & $\begin{array}{c}0.205 \pm \\
0.001 \\
\end{array}$ & $\begin{array}{c}0.037 \pm \\
0.001 \\
\end{array}$ \\
\hline Pyrene & Pyr & $\begin{array}{c}0.044 \pm \\
0.001\end{array}$ & $\begin{array}{c}0.037 \pm \\
0.001\end{array}$ & $\begin{array}{c}0.098 \pm \\
0.001\end{array}$ & $\begin{array}{c}0.117 \pm \\
0.001 \\
\end{array}$ & $\begin{array}{c}0.126 \pm \\
0.001 \\
\end{array}$ & $\begin{array}{c}0.074 \pm \\
0.001\end{array}$ & $\begin{array}{c}0.081 \pm \\
0.001 \\
\end{array}$ & $\begin{array}{c}0.041 \pm \\
0.001\end{array}$ & $\begin{array}{c}0.151 \pm \\
0.001\end{array}$ & $\begin{array}{c}0.026 \pm \\
0.001 \\
\end{array}$ \\
\hline Chrysene & Cry & $\begin{array}{c}0.049 \pm \\
0.001\end{array}$ & $\begin{array}{c}0.044 \pm \\
0.001\end{array}$ & $\begin{array}{c}0.098 \pm \\
0.001\end{array}$ & $\begin{array}{c}0.133 \pm \\
0.001\end{array}$ & $\begin{array}{c}0.101 \pm \\
0.001\end{array}$ & $<0.010$ & $\begin{array}{c}0.078 \pm \\
0.001\end{array}$ & $\begin{array}{c}0.033 \pm \\
0.001\end{array}$ & $\begin{array}{c}0.102 \pm \\
0.001\end{array}$ & $\begin{array}{c}0.022 \pm \\
0.001\end{array}$ \\
\hline Benzo[a]anthracene & B(a)Ant & $\begin{array}{c}0.020 \pm \\
0.001\end{array}$ & $\begin{array}{c}0.020 \pm \\
0.001\end{array}$ & & $\begin{array}{c}0.056 \pm \\
0.001\end{array}$ & $\begin{array}{c}0.060 \pm \\
0.001\end{array}$ & $\begin{array}{c}0.038 \pm \\
0.001\end{array}$ & $\begin{array}{c}0.040 \pm \\
0.001\end{array}$ & & & $\begin{array}{c}0.015 \pm \\
0.001\end{array}$ \\
\hline Benzo[a]pyrene & B(a)Pyr & $\begin{array}{c}0.029 \pm \\
0.001 \\
\end{array}$ & $\begin{array}{c}0.029 \pm \\
0.01 \\
\end{array}$ & $\begin{array}{c}0.062 \pm \\
0.001 \\
\end{array}$ & $\begin{array}{c}0.082 \pm \\
0.001 \\
\end{array}$ & $\begin{array}{c}0.079 \pm \\
0.001 \\
\end{array}$ & $\begin{array}{c}0.052 \pm \\
0.001 \\
\end{array}$ & $\begin{array}{c}0.056 \pm \\
0.001 \\
\end{array}$ & $\begin{array}{c}0.026 \pm \\
0.001 \\
\end{array}$ & $\begin{array}{c}0.082 \pm \\
0.001 \\
\end{array}$ & $\begin{array}{c}0.014 \pm \\
0.001 \\
\end{array}$ \\
\hline Benzo[k]fluoranthene & $\mathrm{B}(\mathrm{k}) \mathrm{FI}$ & $\begin{array}{c}0.014 \pm \\
0.001\end{array}$ & $\begin{array}{c}0.017 \pm \\
0.001\end{array}$ & $\begin{array}{c}0.041 \pm \\
0.001\end{array}$ & $\begin{array}{c}0.049 \pm \\
0.001\end{array}$ & $\begin{array}{c}0.053 \pm \\
0.001\end{array}$ & $\begin{array}{c}0.032 \pm \\
0.001 \\
\end{array}$ & $\begin{array}{c}0.032 \pm \\
0.001\end{array}$ & $\begin{array}{c}0.014 \pm \\
0.001\end{array}$ & $\begin{array}{c}0.057 \pm \\
0.001\end{array}$ & $\begin{array}{c}0.013 \pm \\
0.001\end{array}$ \\
\hline $\begin{array}{l}\text { Indeno[1,2,3-cd] } \\
\text { pyrene }\end{array}$ & Ipyr & $\begin{array}{c}0.020 \pm \\
0.001\end{array}$ & $\begin{array}{c}0.016 \pm \\
0.001\end{array}$ & $\begin{array}{c}0.050 \pm \\
0.001\end{array}$ & $\begin{array}{c}0.071 \pm \\
0.001\end{array}$ & $\begin{array}{c}0.062 \pm \\
0.001\end{array}$ & $\begin{array}{c}0.046 \pm \\
0.001\end{array}$ & $\begin{array}{c}0.041 \pm \\
0.001\end{array}$ & $\begin{array}{c}0.018 \pm \\
0.001\end{array}$ & $\begin{array}{c}0.070 \pm \\
0.001\end{array}$ & $<0.020$ \\
\hline Benzo[b]fluoranthene & $B(b) F I$ & $\begin{array}{c}0.070 \pm \\
0.001\end{array}$ & $\begin{array}{c}0.076 \pm \\
0.001\end{array}$ & $\begin{array}{c}0.167 \pm \\
0.001\end{array}$ & $\begin{array}{c}0.215 \pm \\
0.001\end{array}$ & $\begin{array}{c}0.190 \pm \\
0.008\end{array}$ & $\begin{array}{c}0.133 \pm \\
0.001 \\
\end{array}$ & $\begin{array}{c}0.123 \pm \\
0.001\end{array}$ & $\begin{array}{c}0.068 \pm \\
0.001\end{array}$ & $\begin{array}{c}0.266 \pm \\
0.001 \\
\end{array}$ & $\begin{array}{c}0.057 \pm \\
0.001\end{array}$ \\
\hline Benzo[g,h,i]perylene & $\begin{array}{l}\text { B(g,h,i) } \\
\text { Per }\end{array}$ & $\begin{array}{c}0.027 \pm \\
0.001 \\
\end{array}$ & $\begin{array}{c}0.030 \pm \\
0.001 \\
\end{array}$ & $\begin{array}{c}0.062 \pm \\
0.001 \\
\end{array}$ & $\begin{array}{c}0.079 \pm \\
0.001 \\
\end{array}$ & $\begin{array}{c}0.079 \pm \\
0.001 \\
\end{array}$ & $\begin{array}{c}0.048 \pm \\
0.001 \\
\end{array}$ & $\begin{array}{c}0.048 \pm \\
0.001 \\
\end{array}$ & $\begin{array}{c}0.025 \pm \\
0.001\end{array}$ & $\begin{array}{c}0.080 \pm \\
0.001 \\
\end{array}$ & $<0.025$ \\
\hline $\begin{array}{l}\text { Dibenzo[a,h] } \\
\text { anthracene }\end{array}$ & $\begin{array}{l}\mathrm{Db}(\mathrm{a}, \mathrm{h}) \\
\text { Ant }\end{array}$ & $<0.010$ & $<0.010$ & $\begin{array}{c}0.018 \pm \\
0.001\end{array}$ & $\begin{array}{c}0.023 \pm \\
0.001\end{array}$ & $\begin{array}{c}0.018 \pm \\
0.001\end{array}$ & $\begin{array}{c}0.012 \pm \\
0.001\end{array}$ & $\begin{array}{c}0.018 \pm \\
0.001 \\
\end{array}$ & $<0.010$ & $\begin{array}{c}0.015 \pm \\
0.001\end{array}$ & $<0.020$ \\
\hline \multicolumn{2}{|c|}{ Sum of 16 PAHs } & $\begin{array}{l}0.444 \pm \\
0.004\end{array}$ & $\begin{array}{c}0.432 \pm \\
0.002\end{array}$ & $\begin{array}{l}0.893 \pm \\
0.003\end{array}$ & $\begin{array}{l}1.123 \pm \\
0.005\end{array}$ & $\begin{array}{l}1.081 \pm \\
0.010\end{array}$ & $\begin{array}{c}0.736 \pm \\
0.010\end{array}$ & $\begin{array}{c}0.806 \pm \\
0.010\end{array}$ & $\begin{array}{l}0.406 \pm \\
0.009\end{array}$ & $\begin{array}{c}1.158 \pm \\
0.009\end{array}$ & $\begin{array}{c}2.390 \pm \\
0.014\end{array}$ \\
\hline
\end{tabular}

Average values $\pm \mathrm{SE}, \mathrm{n}=5$; all values are in $\mathrm{mg} . \mathrm{kg}^{-1}$ d.m.; $\mathrm{PAH}<0.0 \mathrm{x}-$ the value has been under the limit of detection (LOD).

period of the pot experiment may have provided enough time for their reduction under the LOD.

High quantities of Benzo[a]anthracene, Benzo[a]pyrene,

Benzo[b]fluoranthene, Benzo[g,h,i]perylene, Benzo[k]fluoranthene, Chrysene and Pyrene were detected in the

Table 7. Mean values of sum of PAHs of individual treatments and their statistical significance

\begin{tabular}{|c|c|c|}
\hline Variant label & Mean value & Fisher LSD test \\
\hline V_001 & 0.444 & $\mathrm{~b}$ \\
\hline V_002 & 0.432 & $\mathrm{~b}$ \\
\hline V_003 & 0.893 & $\mathrm{e}$ \\
\hline V_004 & 1.123 & $\mathrm{f}$ \\
\hline V_005 & 1.081 & $\mathrm{e}$ \\
\hline V_006 & 0.736 & $\mathrm{c}$ \\
\hline V_007 & 0.736 & $\mathrm{~d}$ \\
\hline V_008 & 0.406 & $\mathrm{a}$ \\
\hline V_009 & 1.158 & $\mathrm{f}$ \\
\hline V_010 & 2.390 & $\mathrm{~g}$ \\
\hline
\end{tabular}

Identical letters express statistical non-significance between the treatment, different letters express statistical significance at a significance level $p=0.05$ (Fisher LSD test). unburnt soil (V_009). The high content of the mentioned PAHs can be assigned to dry atmospheric deposition. Benzo[a]pyrene in the ambient air in the CR was investigated in a study carried out by Schreiberová et al. (2020) and the team concluded that the largest amount of Benzo[a]pyrene comes from a combination of several sources which are local heating, heavy industry, and residential sector. Moreover, the unburnt soil had been exposed to the smoke from the piling fires for the whole period of burning, which might have contributed to the content of the afore-mentioned PAHs to a certain extent. Nevertheless, it is evident that there was a certain PAH contamination present even prior the piling burning, which can be assumed from the composition of PAHs.

The BS on which the phytomanagement was not conducted (V_009) showed a high content $\left(2.060 \mathrm{mg} \cdot \mathrm{kg}^{-1}\right)$ of Naphthalene. This was expected, because Naphthalene is formed during the combustion of litter. The content of Naphthalene measured in all other variants was at least 1 or 2 orders of magnitude lower ranging 
between $0.077-0.121 \mathrm{mg} . \mathrm{kg}^{-1}$. This finding demonstrates that the dissipation of Naphthalene was caused by factors other than the application of soil amendments and these could have been its characteristics e.g. a weak binding in the soil and its relative availability to soil organisms which can decompose it. Naphthalene is a volatile substance, so if it is close to the surface, it can escape into the air (CCME, 2010). Moreover, the aeration of the soil induced by the root system of tested plant species could help to reduce the Naphthalene level in the soil. In the research carried out by Vergnoux et al. 2010, the low molar mass PAHs were determined as the major ones formed by forest fire. The Naphthalene levels in the BS were measured to be more than 20 times higher than in the control soils and its amount persisted significant years after the fire (Vergnoux et al., 2011). This has been also confirmed in this study where the Naphthalene levels in the BS were in orders of $\mathrm{mg} \cdot \mathrm{kg}^{-1}$, while in the unburnt soil. the Naphthalene levels were under the limit of detection $\left(<0.010 \mathrm{mg} \cdot \mathrm{kg}^{-1}\right)$, as shown in Table 6.

The sum of 16 PAHs in individual experimental variants is seen in Tables 6 and 7. This value is important, because PAHs occur in nature mainly in mixture. It is noticeable in Figure 2 that experimental variants V_001 (BS supplemented with bentonite and phytomanaged by Lolium perenne), V_002 (BS enriched with compost and phytomanaged by Lolium perenne), and V_008 (unamended BS and phytomanaged by Festuca rubra) had the lowest presence of all analyzed PAHs. While there was no significant difference between treatments V_001 and V_002, the treatment V_008 was significantly different from both of them.
The variants of BS enriched with compost (V_002 and V_006) showed low total values of all PAHs as well. A significant difference was proven between the treatment with Lolium perenne and Festuca rubra species. Compost played a positive role in substituting the soil organic matter that was consumed by the fire and promoted a faster repopulation of the soil by microorganisms. The variants of BS treated with biochar (V_003, V_007) managed to reduce the sum of PAHs compared to the sum of PAHs measured in the BS which was not phytomanaged (V_010). The effect of soil amendments, namely compost and biochar, on the bioavailability of PAHs in multielement polluted soils was investigated in a study by Beesley et al. (2010) who considers biochar and compost as a promising tool in the context of soil remediation from PAHs. Both amendments reduced the concentration of PAHs in the soil, especially the concentration of heavier and toxicologically more severe ones.

The application of soil amendments together with the tested plants affected the $\mathrm{pH}$ values of individual experimental variants (V_001-V_008). The only variants the $\mathrm{pH}$ value of which was not affected by the afore-mentioned factors were untreated burnt and unburnt soil (V_009 and V_010); their $\mathrm{pH}$ values stand out from the $\mathrm{pH}$ values of the rest of the experimental variants. All the values are indicated in Table 8 .

The $\mathrm{pH}$ value differs between burnt and unburnt soil perceptibly. After the piling burn, the $\mathrm{pH}$ of BS rose from 3.4, which was the $\mathrm{pH}$ of the original untreated unburnt soil, to 7.9. All other experimental variants slightly decreased the $\mathrm{pH}$ when compared to the untreated BS. In the available literature on the effects of fire on soil $\mathrm{pH}$ (Certini, 2005), it has been concluded that fire

Table 8. The $\mathrm{pH}$ and dry matter of individual experimental variants

\begin{tabular}{|c|c|c|}
\hline Experimental variant & $\mathrm{pH}[-]$ & d.m. at $105{ }^{\circ} \mathrm{C}[\%]$ \\
\hline V_001 & 7.2 & 88.0 \\
\hline V_002 & 7.3 & 95.8 \\
\hline V_003 & 7.1 & 90.1 \\
\hline V_004 & 6.2 & 82.6 \\
\hline V_005 & 6.4 & 81.8 \\
\hline V_006 & 7.2 & 86.8 \\
\hline V_007 & 6.8 & 96.1 \\
\hline V_008 & 7.1 & 87.9 \\
\hline V_009 & 3.4 & 91.1 \\
\hline V_010 & 7.9 & 77.6 \\
\hline
\end{tabular}

$\mathrm{pH}$ values are means $\pm \mathrm{SE} ; \mathrm{n}=3$; d.m. - dry matter. 
temporarily raises the soil $\mathrm{pH}$ and thus reduces soil acidity. The decrease in soil acidity is mainly due to the burning of soil organic matter and vegetation cover and thus the formation of alkaline ash and its incorporation into the soil. The degree of $\mathrm{pH}$ rise depends on the amount of ash, its chemical composition and annual precipitation (Bülent, 2004). The fire intensity can affect for how long the $\mathrm{pH}$ remains increased in the soil (Scotter, 1963).

The application of compost to the BS resulted in a decrease of $\mathrm{pH}$ from 7.9 ( $\mathrm{pH}$ of untreated BS) to 7.2-7.3, depending on the plant species. Application of compost is a common practice due to its positive effects on soil properties and promotion of soil rhizospheric microorganisms and bacteria. Plants and soil organisms have different preferences on soil $\mathrm{pH}$ (Lamichchane et al., 2016; Nayebzadeh et al., 2017). Compost application can have both liming and acidifying effects, depending on the used input materials and processing conditions (Adugna, 2018).

The ameliorative effect of biochar on acidic soil is broadly known (Zhang et al., 2019; Tamer, 2019); however, the $\mathrm{pH}$ of different types of soils (e.g. alkaline) can be decreased by biochar application, as it is indicated in the study by Zhang et al. (2019). This finding agrees with the results obtained in this study where the enrichment of the BS by biochar caused a decrease of $\mathrm{pH}$ to 7.1 with the treatment with Lolium perenne and to 6.8 with the treatment with Festuca rubra. Both biochar and compost are the materials that can be, and often are, produced from agriculture by-products, the utilization of which in non-processed state can be problematic. Thus, the assisted rhizoremediation of the areas polluted by polycyclic aromatic hydrocarbons can provide a space for the usage of these materials with high added value.

Bentonite is a clay mineral used to enhance nutrient retention in infertile sandy soil (Czabanet al., 2013). During a fire, vegetation cover and soil organic matter are combusted, which causes a rapid release of nutrients. Some elements are volatilized (e.g. N, P, S) during the combustion and other are made more available for the uptake by plants (De Bano, 1991). Bentonite can prevent the released nutrients from being leached in case of severe post-fire precipitations. The $\mathrm{pH}$ in the BS supplemented with bentonite reached 7.2 with the treatment with Lolium perenne, and 6.4 with the treatment with Festuca rubra.
The $\mathrm{pH}$ value is an important parameter affecting the partition coefficient $\left(\mathrm{K}_{\mathrm{ow}}\right)$ of individual PAHs. The $\mathrm{K}_{\mathrm{ow}}$ is an empirical dimensionless property used to predict and indicate how a substance in a medium will distribute itself between an aqueous (hydrophilic) and a non-aqueous (lipophilic) part (Johnsen et al., 2005). The higher the $\mathrm{K}_{\mathrm{ow}}$, the more lipophilic is the substance and therefore less available for microbial decomposition and less mobile in the environment. $\mathrm{K}_{\mathrm{ow}}$ is a function of $\mathrm{pH}$ and temperature, and even small fluctuation of these parameters can affect the behaviour of the substance. As the $\mathrm{pH}$ increases, the $\mathrm{K}_{\mathrm{ow}}$ value decreases; thus, the substance becomes more soluble in water and potentially more available for microbial degradation (Tsai, 2007).

Treatments V_001, V_002, and V_008, which contained the lowest amounts of all monitored PAHs, had the $\mathrm{pH}$ values higher (7.1-7.3) then treatments V_004, V_005, and V_007 where the reduction of PAHs has not been so high $(\mathrm{pH}$ ranging between 6.2-6.8). Therefore, the synergic effect of soil amendments and grass species affected the $\mathrm{K}_{\text {ow }}$ of PAHs, which became more bioavailable for rhizhospheric degradation. This resulted in a considerable reduction of PAH levels in the mentioned experimental variants.

The PCA and RDA analyses were performed on the measured data to capture the interaction between soil amendments, plant species and PAH presence. The RDA analysis defines a spatial arrangement of the monitored PAHs in individual experimental variants. Figure 2 illustrates a spatial arrangement of the monitored PAHs in dependence on individual experimental variants.

The results shown in Figure 2 are significant at the significance level $\alpha=0.043$. On the basis of the level $\alpha$, they are statistically significant. According to the ordination diagram the PAHs occurred mainly in 2 groups which are described below. It is clearly visible that treatments V_001; V_002; V_008 contained the lowest amounts of all monitored PAHs and that Napthalene was affected by factors other than the application of soil amendment and tested plant species (CCME, 2010). The first group of PAHs was found in treatments V_003; V_006; and in even higher content in V_009, these were: Indenopyrene, Benzo[g,h,i] perylene, Benzo[a]anthracene, Fluoranthene, Benzo[b]fluoranthene, Benzo[k]fluoranthene, Pyrene, Chrysene, Benzo[a]pyrene. These 


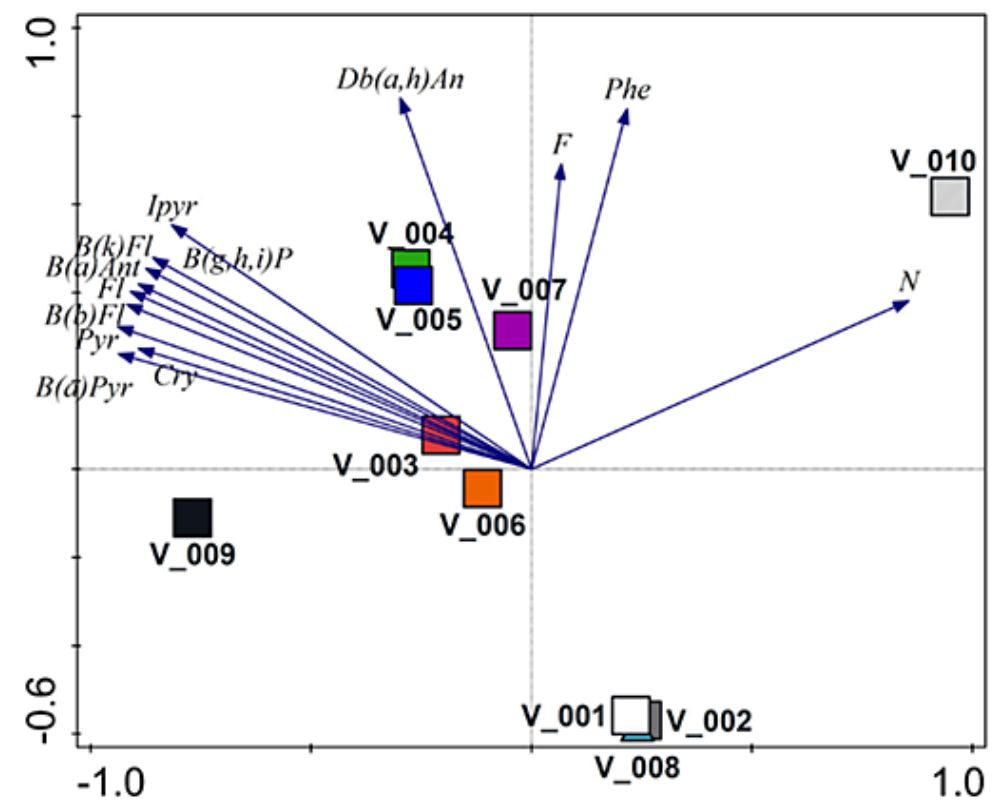

Figure 2. Ordination diagram showing a distribution of PAHs in individual experimental variants (results of RDA analysis; $p s e u d o-F=15.3 ; p=0.001$ )

PAHs were characterized as probable human carcinogens by EPA, see Table 5. The untreated unburnt soil (V_009) shows the highest levels of those PAHs that are typical for dry deposition. The level of these PAHs (Indenopyrene, Benzo[g,h,i]perylene, Benzo[a]anthracene, Benzo[b]fluoranthene, Benzo[k]fluoranthene, Benzo[a]pyrene) stays relatively high for the whole period of the pot experiment. The low $\mathrm{pH}$ of untreated unburnt soil and no remediation action taken for this variant caused a decrease in the availability of these PAHs for microbial degradation and the most evident effect of $\mathrm{K}_{\mathrm{ow}}$ on the bioavailability of PAHs can be observed in this variant. The second group of PAHs occurred primarily in treatments V_004; V_005; and in lower amount also in V_007. These were Dibenzo[a,h]anthracene, Fluorene, and Phenanthrene. Treatments V_004 and V_005 were one of the least effective in reducing the total sum of PAHs. Variant V_005 could have been affected by the root system of Festuca rubra which was not as abundant as the root system of Lolium perenne and therefore less rhizospheric microbes were available for the PAHs degradation. When compared with the variant V 001, where the burnt soil was supplemented also by bentonite and showed high effectiveness in reducing the total sum of PAHs, it is obvious that the root system plays a very important role in degradation of PAHs.

\section{CONCLUSIONS}

The application of soil amendments together with the test grass species induced changes in the burnt soil properties. The most important were an altered $\mathrm{pH}$ value, which had an impact on partition coefficient of individual PAHs, and secondly the improved conditions for plant growth. The altered partition coefficient increased the bioavailability of polycyclic aromatic hydrocarbons for microbial degradation, while owing to a better plant growth, a richer root system on which soil microorganisms thrive was developed.

The effect of application of soil amendments (biochar, compost, and bentonite) to the burnt forest soil on the polycyclic aromatic hydrocarbons level was assessed based on the performed pot experiment with two grass species (Lolium perenne, Festuca rubra). Biochar and compost turned out to be the most effective amendments, regardless of the used grass species. Phytomanaged burnt soil without added amendments demonstrated the potential for dissipation of polycyclic aromatic hydrocarbons as well, but only in the case of Festuca rubra. The best results in reducing the total sum of polycyclic aromatic hydrocarbons were seen with the combination of compost and Lolium perenne. It is obvious that the tested grass species react differently on polycyclic aromatic hydrocarbon contamination, and it is essential to further investigate whether they are appropriate for this kind of phytomanagement. 
Further research should focus on the following areas. The first, carrying out further studies investigating whether multiple plant species and possible combination of effective soil amendments can bring better results in rhizoremediating the fire-affected areas. Secondly, it should be targeted on clarifying how much the polycyclic aromatic hydrocarbon reduction depends on partition coefficient and how partition coefficient changes in the soil with different $\mathrm{pH}$. Lastly, it is recommended to compare the results obtained in this research with the results obtained from a fire-affected area on which a spontaneous bioremediation (colonization with ruderal species of herbs and shrubs) took place.

\section{Acknowledgements}

This research was supported by the program INTER-EXCELLENCE, subprogram INTERCOST of the Ministry of Education, Youth and Sports CR, grant No. LTC2000.

\section{REFERENCES}

1. Abdel-Shafy H.I., Mansour M.S.M. 2016. A review on polycyclic aromatic hydrocarbons: Source, environmental impact, effect on human health and remediation. Egypt. J. Pet., 25(1), 107-123. https:// doi.org/10.1016/j.ejpe.2015.03.011

2. Abdullah S.R.S., Al-Baldawi I.A., Almansoory A.F., Purwanti I.F., Al-Sbani N.H., Sharuddin S.S.N. 2020. Plant-assisted remediation of hydrocarbons in water and soil: Application, mechanisms, challenges and opportunities. Chemosphere, 247, 125932. https:// doi.org/10.1016/j.chemosphere.2020.125932.

3. Adugna G. 2018. A review on impact of compost on soil properties, water use and crop productivity. Res. J. Agric. Sci., 4(3), 93-104. https://doi. org/10.14662/ARJASR2016.010

4. Agoston R. 2018. The effects of global climate change on fire service Human resource view. Procedia Eng., 211, 1-7. https://doi.org/10.1016/j. proeng.2017.12.001

5. Alagić S.Č., Maluckov B.S., Radojičić V.B. 2015. How can plants manage polycyclic aromatic hydrocarbons? May these effects represent a useful tool for an effective soil remediation? A review. Clean Techn Environ Policy, 17, 597-614. https://doi. org/10.1007/s10098-014-0840-6

6. ALS Global. Certificate of Accreditation. 2021 Available at: https://www.alsglobal.cz/media-cz/ certificates/2021/13_2021_eng_whole_cai-pdf.pdf

7. Aponte C., de Groot W.J., et al. 2016. Forest fires and climate change: causes, consequences and management options. Int. J. Wildland Fire, 25 (8), I-II. https://doi.org/10.1071/WFv25n8_FO

8. Alexander M. 1995. How Toxic Are Toxic Chemicals in Soil? Environ. Sci. Technol., 29(11), 27132717. https://doi.org/10.1021/es00011a003

9. Beesley L., Moreno-Jiménez E., Gomez-Eyles J.L. 2010. Effects of biochar and greenwaste compost amendments on mobility, bioavailability and toxicity of inorganic and organic contaminants in a multi-element polluted soil. Environ. Pollut., 158(6), 2282-2287. https://doi.org/10.1016/j. envpol.2010.02.003

10. Bodí M.B., Martin D.A., Balfour V.N., Santín C., Doerr S.H., Pereira P., Cerdà A., Mataix-Solera J. 2014. Wildland fire ash: Production, composition and eco-hydro-geomorphic effects. Earth-Science Reviews, 130, 103-127. https://doi.org/10.1016/j. earscirev.2013.12.007

11. Bülent S. 2004. Soil organic matter, soil pH and soil nutrient dynamics in forest stands after fire. Conference: International Soil Congress on „Natural Resource Management for Sustainable Development", Erzurum, Turkey, June 7-10, Available at: https:// www.researchgate.net/publication/288828677 Soil_organic_matter_soil_pH_and_soil_nutrient_ dynamics_in_forest_stands_after_fire

12. Certini G. 2005. Effects of Fire on Properties of Forest Soils: A Review. Oecologia, 143(1), 1-10. https://doi.org/10.1007/s00442-004-1788-8.

13. Centralni kompostarna. 2020. Produkty. Available online: https://www.centralnikompostarna. cz/24812-kompost-cerny-drak-organicke-hnojivo

14. Chang B.V., Chang S.W., Yuan S.Y. 2003. Anaerobic degradation of polycyclic aromatic hydrocarbons in sludge. Adv Environ Res., 7(3), 623-628. https://doi.org/10.1016/S1093-0191(02)00047-3.

15. Council of Ministers of the Environment. 2010. Canadian soil quality guidelines for the protection of environmental and human health: Carcinogenic and Other PAHs. In: Canadian environmental quality guidelines, 1999, Canadian Council of Ministers of the Environment, Winnipeg. Available at: https:// ccme.ca/en/res/polycyclic-aromatic-hydrocarbons2010-canadian-soil-quality-guidelines-for-the-protection-of-environmental-and-human-health-en.pdf

16. Culek M., Grulich V., Laštůvka Z., Divíšek J. 2013. Biogeografické regiony České republiky. 1st ed, Masarykova univerzita: Brno, Czech Republic, 209-219. https://doi:10.5817/CZ.MUNI. M210-6693-2013.

17. Chanda S., Mehendale H.M. 2005. Acenaphthene. $2^{\text {nd }}$ ed, Editor(s): Philip Wexler, Encyclopedia of Toxicology, Elsevier, 11-13. https://doi.org/10.1016/ B0-12-369400-0/00007-7

18. De Bano L.F. 1991. The effect of fire on soil properties. In: Harvey, Alan E.; Neuenschwander, Leon F., 
compilers. Proceedings-management and productivity of western-montane forest soils; 1990 April 1012; Boise, ID. Gen. Tech. Rep. INT-280. Ogden, UT: U.S. Department of Agriculture, Forest Service, Intermountain Research Station, 151-156. Available online: https://www.fs.usda.gov/treesearch/pubs/42163.

19. Desai A.M., Autenrieth R.L., Dimitriou-Christidis P., McDonald T.J. 2008. Biodegradation kinetics of select polycyclic aromatic hydrocarbon $(\mathrm{PAH}) \mathrm{mix}-$ tures by Sphingomonas paucimobilis EPA505. Biodegradation, 19, 223-233. https://doi.org/10.1007/ s10532-007-9129-3.

20. Desai J.D., Banat I.M. 1997. Microbial production of surfactants and their commercial potential. Microbiol Mol Biol Rev., 61(1), 47-64. https://doi. org/10.1128/mmbr.61.1.47-64.1997.

21. Doerr S.H., Santín C. 2016. Global trends in wildfire and its impacts: perceptions versus realities in a changing world. Philos. Trans. R. Soc. Lond., B, Biol. Sci., 371, 20150345. https://royalsocietypublishing.org/doi/10.1098/rstb.2015.0345

22. Dudaite J., Pereira P., Baltrènaitè-Gedienè E. 2011. Temperature effects on ash colour of forest litter. Moksl. Liet. ateitis., 3, 18-23. https://doi. org/10.3846/mla.2011.081

23. Eskandary S., Tahmourespour A., Hoodaji M., Abdollahi A. 2017. The synergistic use of plant and isolated bacteria to clean up polycyclic aromatic hydrocarbons from contaminated soil. J. environ. health sci., 15(1), 1-8. https://doi.org/10.1186/ s40201-017-0274-2

24. Faboya O.L., Sojinu S.O., Oguntuase B.J., Sonibare O.O. 2020. Impact of forest fires on polycyclic aromatic hydrocarbon concentrations and stable carbon isotope compositions in burnt soils from tropical forest, Nigeria. Scientific African., 8, e00331. https://doi.org/10.1016/j.sciaf.2020.e00331

25. Ferraro A., Massini G., Valentina Mazzurco Miritana V.M., Panico A., Pontoni L., Race M., Rosa S., Signorini A., Fabbricino M., Pirozzi F. 2021. Bioaugmentation strategy to enhance polycyclic aromatic hydrocarbons anaerobic biodegradation in contaminated soils. Chemosphere, 275. https:// doi.org/10.1016/j.chemosphere.2021.130091

26. Goldblum D., Lesley R.S. 2009. Throughfall in pH in a Mixed Deciduous-Coniferous Forest, Ontario, Canada: The Effect of Overstory Species Composition. The Michigan Botanist., 48(3), 65-71. http:// hdl.handle.net/2027/spo.0497763.0048.301

27. Czaban J., Siebielec G. 2013. Effects of Bentonite on Sandy Soil Chemistry in a Long-Term Plot Experiment (II). Effect on pH, CEC, and Macro- and Micronutrients. Pol. J. Environ. Stud., 22, 1669-1676.

28. Fernandez-Anez N., Krasovskiy A., Müller M., et al. 2021. Current Wildland Fire Patterns and Challenges in Europe: A Synthesis of National
Perspectives. Air, Soil and Water Research. https:// doi:10.1177/11786221211028185.

29. Girardin V., Grung M., Meland S. 2020. Polycyclic aromatic hydrocarbons: bioaccumulation in dragonfly nymphs (Anisoptera), and determination of alkylated forms in sediment for an improved environmental assessment. Scientific Reports, 10, 10958. https://doi.org/10.1038/s41598-020-67355-1

30. Huang H., Ye L. 2020. Chapter 9 - Biological technologies for cHRPs and risk control, Editor(s): Hongqiang Ren, Xuxiang Zhang, High-Risk Pollutants in Wastewater. Elsevier, 209-236. https://doi. org/10.1016/B978-0-12-816448-8.00009-5.

31. Johnsen A.R., Wick L.Y., Harms H. 2005. Principles of microbial PAH-degradation in soil. Environmental Pollution, 133(1), 71-84. https://doi. org/10.1016/j.envpol.2004.04.015

32. Kukavica B., Quartacci M.F., Veljovic-Jovanovic S., Navari-Izzo F. 2007. Lipid composition of pea (Pisum sativum L.) and maize (Zea mays L.) root plasma membrane and membrane-bound peroxidase and superoxide dismutase. Arch. Biol. Sci., 59(4), 295-302. https://doi.org/10.2298/ABS0704295K.

33. Lamichhane S., Krishna K.C.B., Sarukkalige, R. 2016. Polycyclic aromatic hydrocarbons (PAHs) removal by sorption: A review. Chemosphere, 148, 336-353. https://doi.org/10.1016/j. chemosphere.2016.01.036

34. Martínez Barroso P., Vaverková M.D. 2020. Fire Effects on Soils - A Pilot Scale Study on the Soils Affected by Wildfires in the Czech Republic. Journal of Ecological Engineering, 21(6), 248-256. https:// doi.org/10.12911/22998993/123471.

35. Menzie C.A, Potocki B.B., Santodonato J. 1992. Exposure to carcinogenic PAHs in the environment. Environ. Sci. Technol., 26, 278-1284. https:// doi:10.1021/es00031a002

36. Mi J., Gregorich E.G., Xu S., McLaughlin N.B., Ma B., Liu J. 2017. Effect of bentonite amendment on soil hydraulic parameters and millet crop performance in a semi-arid region. Field Crops Res., 212, 107-114. https://doi.org/10.1016/j.fcr.2017.07.009

37. Nayebzadeh M., Vahedpour M. 2017. A Review on Reactions of Polycyclic Aromatic Hydrocarbons with the Most Abundant Atmospheric Chemical Fragments: Theoretical and Experimental Data. Progress in Reaction Kinetics and Mechanism., 201-220. https://doi.org/10.3184/14686781 7X14821527549293

38. Patel A.B., Shaik S., Jain K.R., Desai C., Madamwar D. 2020. Polycyclic Aromatic Hydrocarbons: Sources, Toxicity, and Remediation Approaches. Frontiers in Microbiology, 11, 2675. https://doi. org/10.3389/fmicb.2020.562813

39. Pereira P., Francos M., Brevik E.C., Ubeda X., Bogunovic I. 2018. Post-fire soil management. Curr 
Opin Environ Sci Health, 5, 26-32. https://doi. org/10.1016/j.coesh.2018.04.002

40. Pladias. Database of the Czech Flora and Vegetation. Department of Botany and Zoology Faculty of Science Masaryk University, 2018. Available online: https://pladi as.cz/en/

41. Prauhel. 2020. Výroba. Available online: http:// prauhel.cz/prauhel/

42. Radziemska M., Gusiatin Z., Bilgin A. 2017. Potential of using immobilizing agents in aided phytostabilization on simulated contamination of soil with lead. Ecological Engineering, 102, 490-500. https:// doi.org/10.1016/j.ecoleng.2017.02.028

43. Raudonytè-Svirbutavičienè E., Stakènienè R., Jokšas K., Valiulis D., Byčenkienė S., Žarkov A. 2022. Distribution of polycyclic aromatic hydrocarbons and heavy metals in soil following a large tire fire incident: A case study. Chemosphere, 286(1), 131556. https://doi.org/10.1016/j. chemosphere.2021.131556

44. Ren K., Wei Y., Li J., Han C., Deng Y., Su G. 2021. Polycyclic aromatic hydrocarbons (PAHs) and their derivatives (oxygenated PAHs, azaarenes, and sulfur / oxygen-containing heterocyclic PAHs) in surface soils from a typical city, south China. Chemosphere, 283, 131190. https://doi.org/10.1016/j. chemosphere.2021.131190

45. Roslund M.I., Grönroos M., Rantalainen A.L., Jumpponen A., Romantschuk M., Parajuli A., Hyöty H., Laitinen O., Sinkkonen A. 2018. Half-lives of PAHs and temporal microbiota changes in commonly used urban landscaping materials. Peer J., 6, e4508. https://doi.org/10.7717/peerj.4508

46. Schreiberová M., Vlasáková L., Vlček O., Šmejdíŕová J., Horálek J., Bieser J. 2020. Benzo[a] pyrene in the Ambient Air in the Czech Republic: Emission Sources, Current and Long-Term Monitoring Analysis and Human Exposure. Atmosphere, 11(9), 955. https://doi.org/10.3390/atmos11090955.

47. Scotter G. 1963. Effects of forest fires on soil properties in northern Saskatchewan. For. Chron., 39, 412-421. https://doi.org/10.5558/tfc39412-4

48. Straube W.L., Nestler C.C., Hansen L.D., Ringleberg D., Pritchard P.H., Jones-Meehan J. 2003. Remediation of Polyaromatic Hydrocarbons (PAHs) through Landfarming with Biostimulation and Bioaugmentation. Acta Biotechnol., 23, 179-196. https://doi. org/10.1002/abio.200390025

49. Tamer M.S., Refaie K.M., Sherif A.E., Eid M.A.M. 2019. Biochar application in alkaline soil and its effect on soil and plant. Acta Agric. Slov., 114, 85-96. http://dx.doi.org/10.14720/aas.2019.114.1.10

50. Ter Braak C.J.F., Šmilauer P. 2012. Canoco reference manual and user's guide: software for ordination (version 5.0). Microcomputer Power: Ithaca, USA, 496.

51. Terzano R., Rascio I., Allegretta I., Porfido C., Spagnuolo M., Khanghahi M.Y., Crecchio C., Sakellariadou, F., Gattullo, C.E. 2021. Fire effects on the distribution and bioavailability of potentially toxic elements (PTEs) in agricultural soils. Chemosphere, 281, 130752. https://doi.org/10.1016/j. chemosphere.2021.130752.

52. Tsai W.T. 2007. Environmental risk assessment of hydrofluoropolyethers (HFPEs), Journal of Hazardous Materials, 139(2), 185-192. https://doi. org/10.1016/j.jhazmat.2006.10.025.

53. Tsibart A.S., Gennadiev A., Koshovskii T., Watts A.C. 2014. Polycyclic aromatic hydrocarbons in post-fire soils of drained peatlands in western Meshchera (Moscow region, Russia). Solid Earth, 5(2), 1305-1317. https://doi.org/10.5194/se-5-1305-2014

54. United States Environmental Protection Agency. 2021. IRIS Assessments. Available online: https:// iris.epa.gov/AtoZ/

55. Wang Z., Yang C., Brown C., Hollebone B., Landriault M. 2008. A case study: distinguishing pyrogenic hydrocarbons from petrogenic hydrocarbons. Int. Oil Spill Conf. Proc., 1, 311-320. https://doi. org/10.7901/2169-3358-2008-1-311

56. Vergnoux A., Malleret L., Asia L., Doumenq P., Theraulaz F. 2011. Impact of forest fires on PAH level and distribution in soils. Environ Res., 111(2), 193198. https://doi.org/10.1016/j.envres.2010.01.008

57. Wei S., Pan S. 2010. Phytoremediation for soils contaminated by phenanthrene and pyrene with multiple plant species. J. Soils Sediments., 10(5), 886-894. https://doi.org/10.1007/s11368-010-0216-4

58. Yang Y., et al. 2015. Long-term changes in soil $\mathrm{pH}$ across major forest ecosystems in China. Geophys. Res. Lett., 42, 933-940. https://doi. org/10.1002/2014GL062575

59. Zelinkova Z., Wenzl T. 2015. The Occurrence of 16 EPA PAHs in Food - A Review. Polycycl Aromat Compd., 35(2-4), 248-284. https://doi.org/10.1080 /10406638.2014.918550

60. Zhang M., Riaz M., Zhang L., El-desouki Z., Jiang C. 2019. Biochar Induces Changes to Basic Soil Properties and Bacterial Communities of Different Soils to Varying Degrees at $25 \mathrm{~mm}$ Rainfall: More Effective on Acidic Soils. Frontiers in Microbiology, 10. https://doi.org/10.3389/fmicb.2019.01321

61. Zhou M., Li Q., Wang X., Huang Q., Cang L. 2022. Electrokinetic combined peroxymonosulfate (PMS) remediation of PAH contaminated soil under different enhance methods. Chemosphere, 286(1), 131595. https://doi.org/10.1016/j. chemosphere.2021.131595 